\title{
Community Interpreting and linguistics: A fruitful alliance? A survey of linguistics-based research in CI
}

\author{
Carmen Valero Garcés \\ University of Alcalá
}

Since the first Critical Link Conference in Geneva Park, Canada, in 1995, Community Interpreting (CI) has experienced a dramatic change in both theory and practice. National and international conferences, seminars, courses, and workshops all around the world have made it possible for practitioners, trainers, and researchers to get together and discuss their views and exchange ideas. At the same time, an ever-growing flow of publications reflects the enormous activity in this field. Nevertheless, CI research is still far from being in the same category as in fields such as conference interpreting or translation, and this is all the more so for linguistics-based CI research.

As a researcher working in a department mostly involved with linguistics and related areas but with an increasing interest in cultural studies and translation studies, it is my intention to analyze and classify the contributions to CI conferences and the publications of CI papers using a linguistics-based methodology. To begin with, the evolution of linguistics and those sub-areas, which have had the greatest influence in the last few decades, will be briefly discussed, as will its methodologies. Secondly, an analysis will be presented of the characteristics and tools of linguistics-based CI research. And thirdly, conclusions will be drawn concerning the evolution, trends or gaps in CI research in general, and in linguistics-based CI research in particular.

\section{Introduction: Applied Linguistics and Community Interpreting}

Generally speaking linguistics can be classified into three main branches: theoretical linguistics, diachronic linguistics, and applied linguistics (AL). The latter is the one used as a framework in this paper, its main objective being the description of the relationships between linguistic signs and reality.

The boundaries of AL are flexible and are constantly changing and developing, which means that new horizons can - and in fact do - appear and new areas of research need to be incorporated. One only needs to remember Bar-Hillel's (1971) definition of Semantics as the "waste-basket of syntax," and Mey's definition of Pragmatics as "the waste-basket of linguistics" (Mey 2001: 19) to observe that nowadays they are both fully recognised and independent areas in AL. 
In his important book Tres paradigmas de la investigación lingüística, Alcaraz (1990) studies the evolution of linguistics, identifying three linguistics research paradigms in the second half of the 20th century: structuralism, generativism, and pragmatics.

After structuralism, based on the analysis of the structure of language, transformational grammar followed with its 'generativism', seeking the strict formalisation of language and the formulation of a hypothesis regarding the way language works. The last quarter of the century saw the development of the pragmatics paradigm with an interest in discourse analysis, language use and in the functions (more than the forms) that language performs in communication. ${ }^{1}$

Out of this third focus, which is of prime interest to this paper, new theories and new disciplines evolved like conversation analysis, (critical) discourse analysis, text linguistics, cognitive linguistics, and so on. And, of course, the technological revolution and the application of computer tools to linguistics brought about other new disciplines, such as computational linguistics, corpus linguistics, or natural-language processing.

It is precisely within this last paradigm - pragmatics - that most of the linguistics-based research has been done in the field of translation and, hence, also of interpreting and CI, all considered part of 'Translation Studies' (TS). The importance and influence of the pragmatic paradigm in TS and CI are thus probably due to a chronological coincidence, since CI research would not be incorporated in AL and TS until well into the 1990s, at a time when pragmatics and discourse analysis were in full expansion, though the communicative and functional grounding of the pragmatic paradigm obviously fitted CI like a glove.

Pragmatics after all is the study of language in use, i.e. the study of the relationship that exists between linguistic signs and their users in context. The unit is not merely the sentence or the word, but rather the discourse or text; it is not the form, but rather the function. The linguistic data for research come from authentic language, not artificial or invented language. To analyse it, other contributions or influences from disciplines such as psychology, sociology, semiotics or cultural studies, among others, are brought to bear on it. In other words, the pragmatic paradigm is by definition interdisciplinary and its ultimate research goal is the study of the discursive or communicative competence, a term Hymes (1974) introduced to refer to the social, cultural, and psychological rules that govern the use of language in different social contexts.

Thus traditional language-analysis theories and models in pragmatics such as speech act theory (Searle 1969), the cooperative principle (Grice 1975, 1978), theory of politeness (Brown \& Levinson 1978), relevance theory (Sperber \& Wilson 1986), text linguistics (Beaugrande 1981), and discourse analysis (Van Dijk 1985), coexist with new sub-areas such as crosscultural pragmatics or disciplines such as sociolinguistics, linguistic anthropology, or intercultural communication which help to study language from other perspectives. The studies on the 'use' of language by these authors 
have given rise to a large number of texts, expanding and clarifying the meaning of language in action.

Nevertheless, few of these theories have as yet found a place in CI research, while others have yet to be applied. It is surprising, really, that there are so few CI studies that are based on AL when language use is, after all, fundamental to the work of interpreters. The influence of AL can be traced in a large number of studies done on written texts, and mostly on literary translations (for Spain see Ortega 2003). Research on interpreting, however, seems to have followed other paths and does not seem to have allowed itself to be influenced until well into the 1990s by the theories of AL currently in use. In the case of CI, where greater emphasis has always been put on the influence of cultures, the debate on codes of conduct or the fight for the recognition of $\mathrm{CI}$ as a profession have generated much more ink than have linguistic studies.

But one would do well to heed Ullyat's (1999: 251-252) comments on the importance of language:

Interpreters are not just "conduits." It is their task to encourage conversation management, to initiate exchanges, to ask questions, and to seek information which may be vital to a successful outcome of the interpreting assignment. It is not their task to empower anybody, but to take power and responsibility for themselves. In order to do this, although others working in the field of dialogue (e.g. community) interpreting might not consider language skills a top priority for interpreters, I would suggest that it is precisely these language skills that should be accorded top priority. But - and this is very important - by language skills I mean more than purely grammatical or linguistic skills. We need to look at the skills of interpreting the whole communication within all the other societal contexts of speech such as speech event, the speech situation, and the speech community.

At which point Ullyat quotes Lakoff saying:

How well language is used translates directly into how well one's needs are met, into success or failure, climbing to the top of the hierarchy or settling around the bottom, into good or bad relationships, intimate and distant. Language allocates power through politics, defines and determines it, decides its efficacy (Lakoff 1990: 13).

Which for Ullyat (ibid.) - and the author of this contribution - means that:

Thus, both the users and the providers of interpreting services need interpreters who use the language well, so that they can 
both have their needs met in the establishment of good relationships between them.

\section{1. $A L$ research in $\mathrm{CI}$}

The corpus that we have selected for analysis consists of the Critical Link publications in book form and on line, the 2005 IATIS yearbook, the publications that came out of the two international conferences on CI held at the University of Alcalá (2002, 2005), articles that have appeared in journals such as Interpreting, The Translator, Jostrans, and Translation Directory, papers specifically related to CI from conferences or collections of essays, as well as Internet search results.

The sampling is without a doubt incomplete and may even seem limited. However, we believe that it is representative enough to analyse the relationship between AL and CI and to discuss the place linguistics-based research holds within the whole of CI research.

Just to illustrate the lack of AL articles in CI: the Critical Link 3 publication (Brunette et al. 2003) contains 21 articles but only two of them present linguistics-based research (Meyer et al. 2003 and Jacobsen 2003), and in the bibliography for the entire volume, the number of entries out of more than 150 that refers directly to linguistic aspects can be counted on the fingers of one hand. In the case of the international conferences, at the one held at the University of Alcalá, Madrid, Spain in 2002 (see Valero Garcés \& Mancho 2002), none of the 35 papers dealt with linguistics; in 2005 (see Valero Garcés 2005), only one paper (Lindquist 2005) out of 37 papers applied discourse analysis and corpus linguistics techniques to audio recordings and text-transcriptions of interpreted renderings.

It must be said that this shortage of research is probably not a reflection on the relevance of AL to CI. The reasons why there are so few empirical AL studies on CI are manifold:

- There is the late incorporation of CI into the academic world, hence also in its linguistics departments.

- Many CI researchers come from different disciplines, mainly from the social sciences, some from conference interpreting. Most have little or no background in linguistics, whereas those who know the techniques or theories of both $\mathrm{CI}$ and linguistics have taken much more interest in cross-linguistic approaches.

- A final reason for now may be that in CI there are often serious difficulties in gathering corpora of authentic data. The interest that providers (governmental agencies, private institutions, or non-governmental organisations (NGOs)) as well as the users-clients have in keeping the information confidential, contributes to this shortage of data and studies. This situation is often compounded by the fact that it is usually necessary to prepare very detailed reports for those organisations or institutions that do agree to participate in CI re- 
search, to carefully explain the purpose, the use and protection of the data being solicited, only to be rejected dozens of times. In order to be able to carry out CI research, one needs to gain the trust of providers, clients and interpreters often through written authorisation in different minority languages so that the clients are able to understand the researchers' aims firsthand and can sign the forms granting permission to observe and possibly record the sessions as long as their anonymity is preserved.

However, we seem to have reached a turning-point by now and the lack of studies mentioned above is gradually disappearing. Year after year the number of publications and congresses directly related to $\mathrm{CI}$ is on the rise and the number of MPhil theses and Ph.D. dissertations on CI is also growing.

For example, between March and May 2005 two international conferences directly related to CI were held, one at the Heriot-Watt University in Edinburgh (UK) and the other at the University of Alcalá in Madrid (Spain). A third international conference was held at the University of Graz (Austria) entitled "Translation as a social practice" which included a section on CI. In 2006, the IATIS II International Congress also had a section dedicated to CI; in 2007, Critical Link V will be held in Australia; and in 2008, the III International Conference on CI at the University of Alcalá, Spain, will take place.

\section{The methodology of AL research in CI}

Linguistic research on $\mathrm{CI}$ follows the tenet of the pragmatic paradigm, which is the use of the deductive method. For this reason, articles usually present their research following these steps:

1. formulation of a problem (e.g. the message of the interpreter does not coincide with that of speaker 1$)$;

2. data collection through observation (e.g. questionnaires, surveys, interviews);

3. elaboration of a hypothesis (e.g. changes in the reformulation of the message);

4. verification and confirmation of the hypothesis formulated.

This is an observational and experimental method, the goal of which in linguistics is twofold:

1. to formulate theories on the observable linguistic phenomena, and

2. to describe these phenomena in a scientific way.

In this sense, the more descriptive studies there are, the easier it will be to extract general theories that may help to unify CI and provide it with independence and recognition. 
According to Pöchhacker (2004: 79), CI research really took off on the wings of the development of the dialogic-discourse-based interaction (DI) paradigm in the 1990s with empirical studies on e.g. turn-taking (Apfelbaum 1995), on the concepts of "power" and "face" (Baker 1997) or on the myth of the interpreter's neutrality in "sign language" (Metzger 1999). Wadensjö's landmark study Interpreting as Interaction (rev. ed. 1998), Roy's (1996) article “An Interactional Sociolinguistic Analysis of TurnTaking in an Interpreted Event" and her book-length study Interpreting as a Discourse Process (2000), together with the 1999 special issue of The Translator (5: 2) and Mason's (2001) Triadic Exchanges. Studies in Dialogue Interpreting, among others, are examples of the impetus behind CI as it became a research topic at a moment when studies on discourse analysis were at their peak.

This alliance continues to exist and, without a doubt, is beneficial to both. Nevertheless, the exceptional development of interpretation research in conference interpreting that Pöchhacker describes, does not seem to have happened to the same extent and with the same vigour in CI, which still seems mainly preoccupied with the fight to be recognised as a profession. Take, for example, text linguistics and CI. Pöchhacker himself (1992) used the concept of "text as a communicative event" (de Beaugrande \& Dressler 1989, de Beaugrande 1981) and the concept of "textuality" (by applying seven standards: cohesion, coherence, intentionality, acceptability, informativity, situationality, and intertextuality) to conceptualise the "conference as a communicative event with its own textuality, with a particular communicative purpose, internal structure, and target audience, and labelled this communicative event as a hypertext to foreground the multiple links between its constituent parts" (Pöchhacker 2004: 138). Promising though this may seem for CI, the application of this sort of modelling onto CI does not seem to have happened yet.

On the other hand, Pöchhacker's statement that "the field of interpreting studies (...) has been strongly shaped by conceptual and methodological approaches from other, more established disciplines" (2004: 47), is also true for CI. Conversation analysis and ethno-methodology, sociolinguistics and pragmatics have served as important foundations for emerging studies of liaison or dialogue interpreting since the mid 1980s (Pöchhaker 2004: 50). There are scholars from other disciplines that do not specifically belong to AL but that have had their share of influence on CI, like the sociologists Pierre Bourdieu and Ervin Goffman. Bourdieu's concepts of habitus, field, and symbolic capital are used by Inghilleri (2003) and Angelelli $(2004 a, b)$, and the concepts of "footing" and "face-to-face interaction" have been taken from Goffman and laid the foundations of e.g. Wadensjö's work. But then again, in the area of intercultural communication, the studies by Gumperz \& Hymes (1982) or Scollon \& Scollon (1995) have not yet fully become a framework of reference in CI. Neither have cultural studies in the sense that Cronin (2003) or Wierzbicka (1991) propose in their studies on cross-cultural pragmatics. Likewise, the studies on cognitive linguistics which have made their way into Translation Studies (Shreve 1997; Kilary 
2000 and Mcelhanon 2005) have to this point still not been applied, as is the case with cognitive or indeed corpus linguistics, "the future of empirical studies in translating," Mason claimed on the cover of Olohan's book (see Laviosa 2002 and Olohan 2004).

\section{AL and CI: influences and directions}

When classifying the contributions of AL to CI according to the AL subareas or disciplines in which they are produced, four groups can be identified and ranked in importance in terms of the number of publications. They are:

1. contributions from discourse analysis;

2. contributions from pragmatics and the politeness theory;

3. contributions from systemic functional grammar;

4. contributions from corpus linguistics.

\subsection{Discourse-based contributions}

In her seminal study Roy (2000) approaches interpreting as a discourse process and is primarily concerned with aspects such as turn-taking and management of the flow of talk. The sub-areas she is mostly concerned with are interactional sociolinguistics, conversation analysis, and the ethnography of communication. Her hypothesis is that the interpreter's role is more than that of 'mere' translator or interpreter, and her research highlights the interpreter's active involvement in the interaction. This is the area which still produces the largest number of publications in discourse-based CI research.

This approach is followed by, among others, Valero Garcés (2002, 2003) and Valero Garcés \& Taibi (2004) in their analysis of doctor-patientad hoc interpreter encounters, in which they incorporate the structural elements and characteristics of institutional conversation as proposed by Drew and Heritage (1992) i.e.:

1. participant role assignment;

2. overall structural organisation of the institution and situation, with its own procedure, framework and constraints);

3. sequence organisation;

4. turn design;

5. interactional asymmetries.

Conclusions from this line of research reveal that the interaction between the institutional staff (doctors in this case) and the users (patients), whose linguistic and communicative competence is low, often deviates from the pattern of standard or mainstream interactions. The organisational sequence is sometimes changed, the length of the stages may vary, the insti- 
tutional representatives may need to adapt their language and strategies, and they may need to repair instances of misunderstanding.

The other seminal contribution from discourse-based AL is Wadensjö's (1998), using Goffman's notion of "footing" ("the alignment we take up to ourselves and the others present as expressed in the way we manage the production or reception of an utterance" (1981: 128)). She too established that the interpreter's performance went beyond the 'ideal' interpreting norm of 'just translating', providing a useful taxonomy of a number of discoursal strategies describing how interpreters reformulate the original text. Wadensjö calls the interpreter's reformulations "renditions", identifying the following strategies: close rendition, expanded rendition, reduced rendition, substituted rendition, two-part/multi-part rendition, non-rendition, and zero rendition. She examines empirical data recorded during interpreted-mediated encounters within medical, legal, and social services settings to illustrate what "they do, what they think, what they should do and what others expect them to do in face-to-face institutional encounters" (Wadensjö 1998: 128).

As has often been pointed out, these studies by Wadensjö and Roy have fundamentally questioned the normative character of the traditional literature on CI, looking instead at the actual performances of interpreters in 'real' situations. Since then, more and more researchers are leaning toward an interactive, discourse-oriented approach to interpreting. The proceedings of the first Critical Link selection (1997), for example, show a number of papers applying discourse analysis to interpreting and demonstrating the 'active' role of the interpreters (Fenton 1997; Englund-Dimitrova 1997 and Fowler 1997). This tendency has since been continued by e.g. Davidson (2002, 2001), Metzger (1999), Angelelli (2003, 2004), Meyer et al. (2003) and many others. However, this interest in the analysis of the interpreter's role is not accompanied by an analysis of his/her performance from a linguistic point of view. Many studies so far are too fragmented, based on limited corpora and using discourse analysis as just another tool instead of as a theoretical framework.

Moreover, not only is there a shortage of linguistic research in CI but the research that exists has little influence on the practice of the profession. As Angelelli (2007) points out, a look at the codes of ethics or standards of practice of healthcare interpreting associations or a look at the professional development opportunities offered by community agencies, reveals that there is little dialogue between research and practice and "without empirical research, the practice will continue to be based on opinions and personal experiences rather than on empirically tested and informed theories. The more research produced and disseminated, the more opportunities to share findings and inform practice. This will definitely help strengthen the dialogue between theory and practice."

But there's hope. Healthcare interpreting: Discourse and interaction is a special issue dedicated to discourse-based research on healthcare interpreting (Interpreting, 7, 2 (2005)). The issue testifies to the interest that is emerging in the linguistic approach to CI but it also signals the limits of 
such an approach and above all the need for more interdisciplinary research of this kind. As the editors Miriam Shlesinger and Franz Pöchhacker point out:

Thirty years ago, Lang (1975) observed that "in the field of doctor-patient interaction, language problems are customarily ignored entirely." While progress has undoubtedly been made toward eliminating this blind spot, the medical literature as a whole, where it addresses problems of language and communication at all, is still far from treating foreign-language barriers as a mainstream concern.

Judging from he inaugural editorial of Communication \& Medicine, a new "interdisciplinary journal of healthcare ethics, and society" (Sarangi 2004), the topic of mediated communication is as easily overlooked by communication scholars as by medical researchers. And yet, discourse analysts and sociolinguists of various persuasions have clearly been highly influential in the study of interpreted healthcare encounters. (2005: 161-162)

The same can of course also be said of other settings in CI such as public services or education.

To illustrate where we are in this Al sub-area applied to CI, a brief survey of the five papers in this special issue may be illuminating.

Yvan Leanza (2005: 167-192) discusses the different roles community interpreters assume in the interactions and the processes implicitly connected to each of them. He uses interview data as well as discourse transcripts and presents both qualitative and quantitative findings. On the basis of his observations, Leanza proposes a tighter classification of the interpreter's roles according to their alertness and responses to cultural or linguistic differences:

\begin{tabular}{|l|l|}
\hline System agent & Integration agent \\
Bilingual professional & Welcoming \\
Monolingual & Support-Follow up \\
Professional & \\
\hline Community agent & Linguist agent \\
Cultural informant & Translator $(+/-$ active $)$ \\
Cultural broker & \\
Advocate & \\
\hline
\end{tabular}

Valero Garcés (2005: 193-210) presents the results of a study on doctor-patient interaction in dyadic and triadic exchanges. The analysis is based on transcripts of recordings made at healthcare centres and the methodological approach here is that of institutional discourse analysis as developed by Drew and Heritage (Drew \& Heritage 1992; Heritage 1995, 1997 and Drew $\&$ Sorjonen 1997). The results show that unmediated (monolingual) consultations involving patients with limited proficiency share some traits with 
encounters mediated by an ad hoc interpreter. The corpus consists of authentic discourse data from three different types of doctor-patient interaction: 1) doctor/foreign-language patient; 2) doctor/foreign-language patient/ad hoc interpreter; 3) doctor/foreign-language patient/trained interpreter. The study includes a quantitative analysis to complement the qualitative analysis, which is illustrated with a few excerpts.

Dubslaff \& Martinsen (2005: 211-236) examine the interrelations between the use of direct vs indirect speech by primary participants and by dialogue interpreters, focusing on pronoun shifts and their interactional functions. They study pronoun shifts as illustrations of how participants change their footing, following Goffman (1981). In their analysis of the data, they follow Wadensjö's (1998) expanded model of this framework and her taxonomy of interpreter utterances ("renditions").

Bot (2005: 237-262) analyses six interpreter-mediated therapy sessions and identifies four types of changes in perspective, including "direct representation" as a specific style of reported speech. She discusses two types of changes with respect to "person": the addition of a reporting verb (e.g. "he says"), and the change in personal pronoun (usually from "I" to "he" or "she"). Her findings show that the addition of a reporting verb not only serves to indicate who is speaking but that it also plays a role in the organisation of turn-transfer.

Merlini \& Favaron (2005: 263-302) present an analysis of interpreted speech in a pathology session basing it on conversation analysis (CA) and institutional talk (Drew \& Heritage 1992 and Atkinson \& Drew 1979), specifically that of medical encounters. They conduct a qualitative study of discourse features such as turn-taking, topic development, choice of footing, additions, and prosody.

Other noteworthy examples of discourse-based contributions are Merlini's study (2005), in which she explores the mediating practice in the context of counselling services for immigrants again using Goffman's notion of "footing" and elaborating on Wadensjö's (1998) "reception format" and using the notions of "responder," "recapitulator," and "reporter."

Wadensjö's influence is also present in the research by Jacobsen, Rudvin and Rosenberg. Jacobsen analyzes the strategy of "addition" in legal interpreting (Jacobsen 2002) which complements Wadensjö's “expanded rendition" strategy. She distinguishes three categories of additions, breaking them down into further subcategories as can be seen in the following chart: 


\begin{tabular}{|l|l|}
\hline Additions with no impact on the semantic & Repetitions \\
\cline { 2 - 2 } and/or pragmatic content of the source text & Silent pauses \\
\cline { 2 - 2 } & Voice-filled pauses \\
\cline { 2 - 2 } & False starts \\
\hline $\begin{array}{l}\text { Additions with minimal impact on the } \\
\text { semantic and/or pragmatic content of the } \\
\text { source text }\end{array}$ & Repetitions \\
\cline { 2 - 2 } & Fillers \\
\cline { 2 - 2 } & Paralinguistic \\
\cline { 2 - 2 } & Explaining additions \\
\hline $\begin{array}{l}\text { Additions with significant impact on the } \\
\text { semantic and/or pragmatic content of the } \\
\text { source text }\end{array}$ & Elaborating additions \\
\cline { 2 - 2 } & Emphasising additions \\
\cline { 2 - 2 }
\end{tabular}

Rudvin (2003: 164) presents two cases of triadic exchanges (doctor-patientinterpreter) in which she studies omissions and their impact on this type of exchange. Rudvin argues that the subtle changes in emphasis and "innocent" omissions and additions alter the projection of the patient's own state of health and the gravity of the diagnosis.

Similarly, Rosenberg (2002: 223) conducts a detailed qualitative analysis of his own interpreting performance in a paediatrics ward and, applying Wadensjö's taxonomy for renditions, discovers that in his corpus $40.8 \%$ of interpreter utterances are close renditions, $26.9 \%$ are zero renditions, $19.5 \%$ are non-renditions, $3.6 \%$ are reduced renditions, and $9.2 \%$ are expanded renditions. He concludes that external factors highly influence the interpreter's performance.

The studies briefly surveyed in this section are but a sample of the influence of the important groundbreaking research done by Roy and Wadensjö. Their work, according to Pöchhacker, supplied both a coherent conceptual approach to (dialogue) interpreting and a broad base of discourse-analytical methodology, thus launching a new paradigm for the study of interpreting as dialogue discourse-based interaction (DI). (2004: 79)

\subsection{Contributions from pragmatics and politeness-theory}

The influence of linguistic pragmatics (or pragmalinguistics) can be seen in $\mathrm{CI}$ in some contrastive studies that have applied speech act theory (Searle 1976), Grice's cooperative principle or politeness theory (Brown \& Levinson 1987) in corpora made up of face-to-face interactions in institutional settings.

One of the most influential authors working in this direction is BerkSeligson. Her work (e.g. 1988/2002, 1990) is representative in that it analyzes issues such as politeness and register in a corpus of 114 hours of English - Spanish interpreting in judicial proceedings. She presented two simulated audio recordings of a witness testifying in Spanish through an interpreter. In one recording the politeness markers were interpreted while in the other they were omitted. When the two versions were rated by mock jurors, they came up with a significantly more favourable assessment of the Span- 
ish witness, after having listened to the polite version of the English interpretation. Some other pragmatic shifts were also found to be significant such as the use of non-contracted versus contracted forms; the effect of hedging (the use of "well", "sort of") and the use of passive vs active voice when interpreting into English. Berk-Seligson (1990) showed that the use of such discourse features produced a more negative evaluation of the witness.

Along similar lines, Hale $(2001,2004)$ reports findings about how English-Spanish interpreters handle register and politeness forms in a corpus of Australian court cases. Krouglov (1999) also finds evidence of a number of shifts in the pragmatic force with particular reference to hedges, polite forms, and the implications of footing in the related domain of police interpreting. Mason and Steward (2001), also analysing the discourse of court and police interpreters, once again observe significant shifts in hedging, modality and register, and in politeness. Cambridge (1999: 201219) discusses shifts with respect to politeness (face), common ground and interlocutor roles. Her findings include some examples of face-threatening acts that lead to miscommunication and false impressions.

Another example of a discourse-based analysis using pragmatic concepts, is Pöllabauer's article (2004) "Interpreting in asylum hearings. Issues of role, responsibility and power." She studies authentic asylum hearings, focussing on the description of role expectations as asymmetrical power distribution and on the validity of existing (traditional) norm systems. She too uses Brown \& Levinson's (1987) concept of "face" and Goffman's (1981) concept of "footing" and her findings show that:

Interpreters shorten and paraphrase statements, provide explanations try to save their own - and if possible, also the others participants' - face, and intervene if they deem it necessary. In case of conflicts and potentially face-threatening situations, their behaviour demonstrates that they seek to meet (and anticipate) the officer's expectations. Forging alliances with the officers, however, does not necessarily mean that they show uncooperative behaviour to the asylum-seeker. (2004: 180)

Ullyat (1999) calls attention to shifts in the rendering of speech acts and the risk of misinterpretation in the absence of background knowledge of the interlocutors' world view. She emphasises the importance of developing all of the linguist's skills, ranging from "the formal skills of phonology, morphology, semantics, and discourse to the sociolinguistic skills of interpreting utterances against the background of psychological and social construct." (253).

Finally, Mason (2005) also applied the concept of basic orientation footing (Goffman 1981) in adjacency pairs (e.g. question-answer). He finds that the interpreter introduces changes to the structure of the adjacency pairs, e.g. turning an open question into a preferred-response question. Interpreters thus become a "controller of response questions and they shift or 
re-project a projected identity without this being known to other participants" (2005: 48).

It is clear that, when summarizing the role of pragmatics and politeness in interpreted dialogue, the studies by Goffman ("footing") and Brown \& Levinson ("face") have been most influential. Although the findings of this research cannot automatically be applied to all language and culture pairs they do, however, seem to provide a sound framework for analysis. Rudvin, for example, points out that in Western courtrooms direct communication is expected and required, even though it strongly clashes with those cultures in which indirectness is a politeness marker (e.g. Australian Aboriginal, Philippine Ilingot). In that case, a member of such a different speech community and culture would obviously be at a great disadvantage. However,

If politeness competence is essential for communicative success, i.e. each party's success in obtaining the desired outcome of the exchange (e.g. client acquittal or prosecutor charge), then one's purpose in engaging in the discourse in the first place will be accomplished best by staying within the politeness system, including the use of that form of politeness expected by one's culture in the specific context (2003: 185),

thus pointing once more to the valuable contribution the Al sub-area of pragmatics and politeness theory can make to CI.

\subsection{Contributions from Systemic Functional Grammar}

Systemic Functional Grammar seems to have found a place in CI thanks mainly to the pioneering work by Helen Tebble, an AL-CI researcher working in Australia. She developed a prototype model $(1991,1993)$ for the description and analysis of interpreted consultations. Her work followed that of Halliday and Hasan $(1985,1989)$ in genre theory and systemic functional linguistics. Tebble's model is as follows:

\begin{tabular}{|c|c|}
\hline FIELD & $\begin{array}{l}\text { Presenting a problem that may need to be defined } \\
\text { and for which a solution is required. }\end{array}$ \\
\hline TENOR & $\begin{array}{l}\text { role relationships - hierarchical: } \\
\text { professional: superordinate } \\
\text { client/patient: subordinate } \\
\text { interpreter: independent } \\
\text { social Distance - maximum }\end{array}$ \\
\hline MODE & Constituted of two languages \\
\hline & 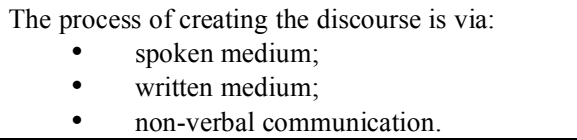 \\
\hline
\end{tabular}




\begin{tabular}{|l|l|}
\hline & Channel \\
& \\
& \\
& $\bullet \quad$ phonic; \\
& eraphic; \\
\hline
\end{tabular}

In this model, "Field" has to do with the nature of the social activity, its topics, goals, and activities. "Tenor" relates to the nature of the relationships of the people participating in the consultation (typically three), in other words, the institutional roles they play (e.g. a professional role such as judge, doctor or social worker; client or patient; and interpreter). The "Mode" of the discourse refers to the roles that both language and the channels of communication play in the context of a professional consultation.

According to Tebble, the contextual configuration can be used to predict the obligatory and optional elements of the discourse structure, their sequence, and their iterative nature. As such, the basic stages of e.g. a prototypical interpreted professional consultation are:

- greetings;

- introductions;

- $\quad$ stating/eliciting problem;

- ascertaining facts;

- diagnosing facts;

- $\quad$ stating resolution;

- client's decision;

- clarifying residual matters;

- conclusion;

- farewells.

In later work, Tebble (1999) added another optional element - contract or role negotiation - which usually takes place during briefing or at the beginning of the consultation. She mentions that at this point the interpreter also assures the patient and physician of his/her complete confidentiality (depending on the ethical requirements of the particular situation and on the interpreter's experience). Acknowledging the importance of other related disciplines such as: discourse analysis, pragmatics, sociolinguistics, conversation analysis, ethnomethodology and social psychology, she identified and described four main different areas of discourse/communication which come into play in any medical interpreting setting (and in other dialogue or CI settings as well, of course):

- a discourse component;

- an interpersonal component;

- a psycholinguistic and neurolinguistic component;

- a socio-cultural component.

Since then, and based on her work, similar analyses have been carried out in the framework of systemic functional pragmatics at the Hamburg Re- 
search Centre on Multilingualism by e.g. Meyer (2001). Bischoff \& Loutan (1999) provide another example focussing on interpersonal components and studying the importance of logistics and kinesics in medical encounters.

\subsection{Contributions from Corpus Linguistics}

CI studies using the methodology of Corpus Linguistics are not very common, possibly because the orality of the material makes it more difficult to work with, but also because of the particular characteristics of the subjects of study such as public service institutions, (sometimes illegal) immigrants, patients, non-professional interpreters, and so on.

It might be necessary to wait, then, for the point when greater collaboration between institutions and researchers becomes possible, when especially institutions and providers begin to realize that this type of research can be to their benefit as well, as it may lead to greater efficiency, cost-reduction and legal as well as professional accountability. We may also have to wait for the moment when recording becomes less intrusive and technology has advanced to the point when all silences, pauses, doubts and interruptions can be tabulated without having to do so manually.

The research that Lindquist (2005) presented at the international conference on CI at the University of Alcalá is as yet an isolated example, as far as we know. Linquist presents an approach that examines interpreter renderings in terms of the conservation of source-text meaning - its rhetorical value and clarity - as well as the mechanics by which the message is altered. Discourse analysis and corpus linguistics techniques are applied to both audio recordings and text-transcriptions of interpreter renderings, making it possible to examine and enumerate observations about both linguistic and paralinguistic aspects of the interpreter's performance. By simultaneously considering interpreter renderings in terms of the conservation of the three universal aspects of a message (meaning (M), rhetorical value (R), and clarity/coherency $(\mathrm{C})$ as well as the mechanics by which that message may be altered, both the cause and effect of deviations in the message are identified.

His study is, as he points out, "at best one small step toward developing a corpus of interpreter renderings to help construct an empirical foundation which may be used to confirm or refute widely held beliefs about the processes and difficulties associated with interpreting in order to improve interpreter training and education." (2005: 242)

\section{Conclusions}

As our survey has shown, the CI studies based on the theories and methodology of Applied Linguistics and more particularly the pragmatic paradigm, are still too few and too new. As is common to this paradigm, the research is 
usually deductive and the data is collected by means of surveys or recordings of real conversations in triadic encounters.

However, the research does seem to be very promising as it is, by its very nature, multidisciplinary. From the first influential studies by Roy and Wadensjö in the 1990s, who started this type of research based on the study of authentic material, concepts from other disciplines such as sociology or intercultural communication were incorporated. Later some other AL areas such as sociolinguistics, discourse analysis, pragmatics or corpus linguistics have been added. However, other AL disciplines such as textlinguistics, cross-cultural pragmatics or linguistic anthropology still remain largely unexplored in their potential for CI.

An attempt at classifying the linguistics-based research on CI has led to the establishment of four groups, though it should be stressed that the multidisciplinary character of AL research in CI is such that the majority of the studies could be placed in more than one of these groups.

In short, the discourse-based methodological orientation within the pragmatic paradigm as well as the diversity of disciplinary approaches taken by the researchers make applied linguistics-based research on CI, although as yet fragmentary and insufficient, extremely rewarding and very promising for the future.

\section{Bibliography}

Alcaraz, Enrique (1990). Tres paradigmas de la investigación lingüistica. Alcoy: Marfil

Angelelli, Claudia (2003)."The Interpersonal Role of the Interpreter in Cross-Cultural Communication". L. Brunette et al. Critical Link 3. Amsterdam: John Benjamins, 15-26.

Angelelli, Claudia (2004a). Medical Interpreting and Cross-Cultural Communication. Cambridge: Cambridge University Press.

Angelelli, Claudia (2004b). The Visible Interpreter: A Study of Community, Conference, Court Interpreters in Canada, Mexico, and United States. Amsterdam: John Benjamins.

Angelelli, Claudia (2007). "The Controversial Role of the CI Interpreter/Translator in the Healthcare Setting: A Plea for a Dialogue between Research and Practice". C. Valero Garcés \& A. Martin (eds). Building Bridges. The controversial role of the CI interpreter/translator.

Apfelbaum, Birgit (1995). "Interaktive Verfahren der Disambiguierung in Situationen des Gesprächsdolmetschens". Kognitionswissenschaft 5(3), 141-50.

Atkinson, John M. \& Peter Drew (1979). Order in Court. The Organization of Verbal Behaviour in Judicial Settings. London: Macmillan.

Baker, Michael (1997). "Non-cognitive Constraints and Interpreter Strategies". K. Simms (ed.). Translating Sensitive Texts: Linguistic Aspects. Amsterdam/Atlanta: Rodopi, 111-129.

Bar-Hillel, Yehoshua (1971). "Out of the pragmatic waste-basket”. Linguistic Inquiry 2, 401-7.

Beaugrande, Robert de (1980). Text, Discourse and Process. London: Longman.

Beaugrande, Robert de \& D. Dresler (1981). An introduction to Textlinguistics. London: Longman.

Berk-Seligson, Susan (1988). "The impact of politeness in witness testimony: the influence of court interpreter". Multilingua 7 (4), 411-439.

Berk-Seligson, Susan $(1990,2002)$. The Bilingual Courtroom. Court Interpreters in the Judicial Process. Chicago, IL: The University of Chicago Press.

Bischoff, Alexander, Claude Tonnerre, Louis Loutan \& Hans Stalder (1999). "Language difficulties in an outpatient clinic in Switzerland". Sozial und Praventivmedizine 44(6), 283-287.

Bot, Hanneke (2005). "Dialogue interpreting as a specific case of reported speech". Interpreting 7(2), 237-262.

Bourdieu, Paul (1997). Outline of a Theory of Practice. Cambridge: Cambridge University Press.

Brown, Penelope \& Stephen C. Levinson (1978). "Universals in language usage; Politeness phenomena”. E. Goody (ed). Style in Language. Cambridge, Mass.: MIT Press, 253-276. 
Brown, Penelope \& Stephen C. Levinson (1987). Politeness: Some Universals in Language Usage. Cambridge: Cambridge University Press.

Brunette, Louise, Georges Bastin, Isabelle Hemlin \& Heather Clarke (eds) (2003). The Critical Link 3: Interpreters in the Community. Selected Papers from the Third International Conference on Interpreting in Legal, Health and Social Service Settings. Amsterdam/Philadelphia: John Benjamins.

Cambridge, Jan (1999). "Information Loss in Bilingual Medical Interviews through an Untrained Interpreter". The Translator 5(2), 201-220.

Cronin, Michael (2003). Translation and Globalization. London \& New York: Routledge.

Davidson, Brad (2000). "The Interpreter as Institutional Gatekeeper: The Social-linguistic Role of Interpreters in Spanish-English Medical Discourse". Journal of Sociolinguistics 4(3): 379405.

Davidson, Brad (2001). "Questions in Cross-linguistic Medical Encounters: The Role of the Hospital Interpreter”. Anthropological Quarterly 74(4): 170-178.

Drew, Paul \& John Heritage (eds) (1992). Talk at Work. Cambridge: Cambridge University Press.

Drew, Paul \& Marja-Leena Sorjonen (1997). "Institutional dialogue". Teun A. Van Dijk (ed.). Discourse as Social Interaction. London: Sage.

Dubslaff, Friedel \& Bodil Martinsen (2005). "Exploring untrained interpreters' use of direct versus indirect speech". Interpreting 7( 2), 211-236.

Englund-Dimitrova, Brigitte (1997). "Degree of Interpreter Responsibility in the interaction process in community interpreting". S. Carr et al. (eds). The Critical Link: Interpreters in the Community. Amsterdam: John Benjamins, 7-26.

Fenton, Sabine (1997). "The role of the interpreter in the adversarial courtroom". S. Carr et al. (eds). The Critical Link: Interpreters in the Community. Amsterdam: John Benjamins, 2934.

Fowler, Yvonne (1997). "The courtroom interpreter. Paragon and intruder?" S. Carr et al. (eds). The Critical Link: Interpreters in the Community. Amsterdam: John Benjamins: 191-200.

Goffman, Ervin (1981). Forms of Talk. Oxford: Blackwell.

Grice, Paul (1975). "Logic and conversation". P. Cole \& J.L. Morgan (eds). Syntax and Semantics, Vol. 3, San Diego: Academic Press, 41-58.

Grice, Paul (1978). "Further notes on logic and conversation". P. Cole (ed.). Syntax and Semantics 9, 113-127.

Gumperz, John. J. (1982). Discourse Strategies. Cambridge: Cambridge University Press.

Hale, Sandra (2001). "How faithfully do Court Interpreters Render the Style of Non-English Speaking Witness's Testimony? A Data-Based Study of Spanish-English Bilingual Proceedings". Discourse Studies 4(1), 25-47.

Hale, Sandra (2004). The Discourse of Court Interpreting. Amsterdam/Philadelphia: John Benjamins.

Halliday, Michael A.K. (1985). An Introduction to Functional Grammar. London: Edward Arnold.

Halliday, Michael A.K. \& Ruqaiya Hasan (1989). Language, Context and Text: Aspects of Language in a Social-Semiotic Perspective. Geelong, VIC: Deakin University Press.

Heritage, John (1995). "Conversation Analysis: methodological aspects". U. M. Quasthoff (ed.). Aspects of oral communication. Berlin: deGruyter, 391-418.

Heritage, John (1997). "Conversation analysis and institutional talk". D. Silverman (ed.). Qualitative Research: Theory, Method and Practice. London: Sage, 161-182.

Hymes, Dean (1974). Foundations in Sociolinguistics. New Jersey: The University of Pennsylvania Press.

Inghilleri, Moira (2003). "Habitus, Field and Discourse: Interpreting as a Socially Situated Activity". Target 15 (2): 243-268.

Jacobsen, Bente (2002). "Additions in court interpreting". G. Garzone et al. Perspectives on Interpreting, Bologna: CLUEB, 235-256.

Jacobsen, Bente (2003). "Pragmatics in Court Interpreting: Additions". L. Brunette et al. (eds) The Critical Link 3: Interpreters in the Community. Amsterdam/Philadelphia: John Benjamins, 223-238.

Kiraly, Dan C. (2000). A Social Constructivist Approach to Translator Education. Empowerment from Theory to Practice. Manchester: St. Jerome.

Krouglov, Alexander (1999). "Police interpreting: politeness and sociocultural context". The Translator 5(2), 285-302.

Lakoff, Robert T. (1990). Talking Power: The Politics of Language in Our Lives. New York: Basic Books.

Lang, Robert (1976). "Orderlies as interpreters in Papua New Guinea". Papua New Guinea Medical Journal, 18(3), 172-177. 
Laviosa, Sara (2002). Corpus-based Translation Studies: Theory, Findings, Applications. Amsterdam: Rodopi.

Leanza, Yvan (2005). "Roles of community interpreters in pediatrics as seen by interpreters, physicians and researchers". Interpreting ,7(2), 167- 192.

Linquist, Peter (2005). "The MRC approach to interpreter performance evaluation: applying discourse analysis and corpus linguistics to the spoken word". C. Valero Garcés \& G. Mancho (eds). Traducción e Interpretación en los Servicios Públicos: Nuevas necesidades para nuevas realidades/ New Needs for New Realities. Alcalá de Henares: Servicio de Publicaciones de la Universidad, 235-242.

Loutan, Louis, Tiziana Farinelli, \& Sandro Pampallona (1999). "Medical interpreters have feelings too". Sozial und Präventivmedizin 44, 280-282.

Mason, Ian (1999). "Introduction”. The Translator 5(5), 147-160.

Mason, Ian (2001). Triadic Exchanges. Manchester: St Jerome.

Mason, Ian (2005). "Projected and perceived identities in dialogue interpreting". J. House et al., (eds). 2005 IATIS Book. Translation and Construction of Identity, Korea: IATIS, 30-52.

Mason, Ian \& Miranda Stewart (2001). "Interactional pragmatics, face and the dialogue interpreter". In I. Mason (ed), Triadic Exchanges. Studies in Dialogue Interpreting. Manchester: St Jerome, 51-70.

Mcelhanon, K. A. (2005). "From word to scenario: The influence of linguistic theories upon models of translation". Journal of Translation 1(3), 29-67.

Merlini, Rafaella. (2005). "Alla ricerca dell'interprete ritrovato”. In Russo, M. \& Mack, G. eds. Interpretazione di trattativa. La mediazione lingusitico-culturale nel contesto formative e professionale. Milano: Hoepli, 19-40.

Merlini, Raffaela \& Roberta Favaron (2005). "Examining the "voice of interpreting" in speech pathology." Interpreting 7(2), 263-302.

Metzger, Melanie (1999). Sign Language Interpreting: Deconstructing the Myth of Neutrality. Washington, D.C: Gallaudet University Press.

Mey, Jacob (1993). Pragmatics. Oxford: Blackwell.

Meyer, Bernd (2001). "How non-trained community interpreters handle medical terms". I. Mason (ed.). Triadic Exchanges. Studies on Dialogue Interpreting. Manchester: St Jerome.

Meyer, Bernd (2002). "Medical interpreting. Some salient features". G. Garzone \& M. Viezzi (eds). Interpreting in the 21st century: Challenges and Opportunities. Amsterdam/ Philadelphia: John Benjamins, 159-169

Meyer, Bernd, Birgt Apfelbaum, Franz Pöchhacker \& Alexander Bischoff (2003). "Analysing interpreted doctor-patient communication from the perspectives of Linguistics, Interpreting Studies and Health Sciences". L. Brunette et al. (eds). The Critical Link 3 Amsterdam/Philadelphia: John Benjamins, 66-79.

Olohan, Maeve (2004). Introducing Corpora in Translation Studies. London \& New York: Routledge.

Ortega, Emilio (ed.) (2003). Panorama actual de la investigación en traducción e interpretación 1(2). Granada: Atrio

Pöchhacker, Franz (2004). Introducing Interpreting Studies. London: Routledge.

Pöchhacker, Franz (2005). "Introduction". Interpreting,7(2), 161.

Pöllabauer, Sonia (2004). "Interpreting in asylum hearings. Issues of role, responsibility and power". Interpreting 6(2), 143-180.

Rosenberg, Brett. A. (2002). "A Quantitative Analysis of Community Interpreting”. C. Valero Garcés \& G. Mancho (eds). Traducción e Interpretación en los Servicios Públicos: Nuevas necesidades para nuevas realidades / New Needs for New Realities. Alcalá de Henares: Servicio de Publicaciones de la Universidad, 113-140. (CD)

Roy, Cynthia (1989). A Sociolinguistic Analysis of the Interpreter's Role in the Turn Exchanges of an Interpreted Event. PhD dissertation, Georgetown University, Washington, DC.

Roy, Cynthia (1996). "An interactional sociolinguistic analysis of turn-taking in an interpreted event". Interpreting 1(1), 39-67.

Roy, Cynthia (2000). Interpreting as a Discourse Process. New York/Oxford: Oxford University Press.

Rudvin, Mette (2003). "Interpreting for public services: some institutional, professional and intercultural aspects". G. Garzone \& M. Rudvin (eds). Domain-Specific English and Language Mediation in Professional and Institutional Settings. Milan: Arcipelago Edizioni, 111-178.

Sarangi, Srikant (2004). "Towards a communicative mentality in medical and healthcare practice". Communication \& Medicine 1(1), 1-11.

Scollon, Ron \& Suzanne W. Scollon (1995). Intercultural Communication. Oxford: Blackwell.

Searle, John (1969). Speech Acts. An Essay in the Philosophy of Language. Cambridge: CUP 
Searle, John R. (1976). “A classification of illocutionary acts”. Language and Society 5, 1-23.

Shlesinger, Miriam \& Franz Pöchhacker (2005). "Introduction”. Interpreting 7(2), 157-166.

Shreve, Gregory (2002). "Knowing Translation: Cognitive and Experiential Aspects of Translation Expertise from the Perspective of Expertise Studies". A. Riccardi (ed.). Translation Studies. Perspectives on an Emerging Discipline. Cambridge: Cambridge University Press.

Sperber, Dan \& Deirdre Wilson (1986) Relevance. Communication and Cognition. Oxford: Blackwell.

Tebble, Helen (1991). "Towards a Theory of interpreting”. P Hellander (ed.). Proceedings of the Conference of the Interpreter and Translator Educators' Association of Australia. Adelaide: South Australian College of Advanced Education, 54-59.

Tebble, Helen (1993). "A discourse model for dialogue interpreting". Proceedings of the First Practitioners' Seminar. Australian Institute of Interpreters and Translators (AUSIT), Canberra, 1-23.

Tebble, Helen (1999). "The Tenor of Consultant Physicians:Implications for Medical Interpreting". The Translator 5(2), 179-200.

Ullyat, Ruth (1999). "The importance of discourse analysis in the training of liaison / community / public service interpreters". M. Erasmus et al. (eds). Liaison Interpreting in the Community. Pretoria: Van Schaik, 250-261.

Valero Garcés, Carmen (2002). "Interaction and conversational constrictions in the relationships between suppliers of services and immigrant users". Pragmatics 12(4), 469- 496.

Valero Garcés, Carmen (2003). "Talk, work, and institutional order: Processes of accommodation in doctor / immigrant patient interaction". I. Palacios Martínez et al. (eds). Fifty Years of English Studies in Spain (1952-2002). A Commemorative Volume. Santiago de Compostela: Universidad de Santiago de Compostela, 663 - 670.

Valero Garcés, Carmen (2005). "Doctor-Patient consultations in dyadic and triadic exchanges". Interpreting 7(2), 193-210.

Valero Garcés, Carmen \& Guzmán Mancho Barés (2002) (Eds). Traducción e Interpretación en los Servicios Públicos: Nuevas necesidades para nuevas realidades/ New Needs for New Realities. Alcalá de Henares: Servicio de Publicaciones de la Universidad.

Valero Garcés, Carmen \& Mustapha Taibi (2004). "Análisis de la interacción comunicativa en contextos institucionales entre proveedores de servicios, usuarios e intermediarios lingüísticos". Oralia 7, 207-228.

Van Dijk, Teun A. (1985). Handbook of Discourse Analysis. Discourse Analysis in Society New York: Academic Press.

Wadensjö, Cecilia (1995). "Dialogue interpreting and the distribution of responsibility". Hermes, Journal of Linguistics 14, 111-129.

Wadensjö, Cecilia (1998). Interpreting as Interaction. London: Longman.

Wierzbicka, Ann. (1991). Cross-Cultural Pragmatics. The Semantics of Human Interaction. Berlin $\&$ New York: Mouton de Gruyter.

1 Alcaraz (1990: 13) clearly explains this paradigmatic evolution: "Just like in other sciences or disciplines, in linguistics progress has also come from a change in paradigm, a change that has also brought with it a jump from one linguistic level or component to another. Therefore, the American structuralism of the 1930s and 1940s put the main emphasis in first in phonology and later in morphology; in the generativist paradigm, the emphasis was first in morphosyntax and later in semantics; and lately, all of the attention is being shifted to discourse research and the use of language in the pragmatic paradigm." 